\title{
PUSHKIN - «DON JUAN» IN THE INTERPRETATION OF P. HUBER AND M. ARMALINSKIY
}

\author{
TATIANA SHEMETOVA \\ M. V. Lomonosov Moscow State University \\ shemetovat@mail.ru \\ ORCID: 0000-0003-3342-8508
}

\section{ABSTRACT}

This article is devoted to the description of the two mythologemes of Pushkin myth (PM). According to the first, the great Russian poet secretly loved one woman all his life and dedicated many unattributed poems to her. This is the mythologeme of Pushkin's hidden love. The other side of the myth is based on the "Ushakova's Album" (her personal notebook for her friends' poetries), in which the poet joked down the names of all his beloveds (Don Juan List). On the basis of this document, the literary critic P. Guber and the "publisher" of Pushkin's Secret Notes, M. Armalinsky, make ambiguous conclusions and give a new life to Pushkin myth in the 20-21 st centuries.

KEYWORDS: the myth of Pushkin, hidden love, Russian literature of the twentieth century, "Don Juan of Pushkin," Pushkin's Secret Notes, P. Guber, M. Armalinsky.

\section{INTRODUCTION: THE STATE OF THE QUESTION}

The application of the concept "Pushkin myth" (PM) is very diverse, which sometimes leads to an unreasonable expansion of the meaning of the term. Like any myth (ancient or modern), the PM is a plot that develops from episodesmythologemes. In this article we will review two mythologemes of the PM: "monogamous Pushkin" and "Pushkin - Don Juan (i. e. ladies' man)."

P. Guber studied in detail the page of "Ushakova's Album" with an ironic list of poet's beloveds in monograph Don Juan list of Pushkin and came to an assumption paradoxically consistent with mythologeme of hidden (the only) love: "unhappy love has always been the most prolific and lucky muse" (1993: 217).

Moreover, Guber proved that "Don Juan list of Pushkin" in both of its parts is far from full (i. e. Pushkin indicated not all his beloveds there). Nevertheless, Guber supported the opposite mythologeme of the poet's hidden love and supposed that that hidden love was countess N. V. Kochubey.

"I loved you once..." is a famous elegy written by Pushkin in 1829, before he married N. N. Goncharova. This elegy is regarded as ending the plot of automythologeme "hidden love" in Pushkin's poetry. As a rule, the elegy was not considered by Pushkin scholars who studied the problem of "hidden love," since the elegy was regarded as evidently attributive: the addressee was thought to be A. A. Olenina. E. Egorova considered all the main hypotheses about attribution of "I loved you once...," existing in modern Pushkin studies in her 
book Shelter of Brooding Dryads. There turned to be five possible addressees: A. A. Olenina, K. A. Sobanskaya, N. N. Goncharova, A. P. Kern and M. N. Volkonskaya.

The final resolution of the dispute among Pushkin scholars for the use of this attribution is hampered by the absence of unequivocal evidence or Pushkin's marks. ${ }^{1}$ This may indicate that Pushkin deliberately hid the addressee's name in order to keep in readers' consciousness the automyth about the mysterious beloved who passed through poet's entire life. In other words, if another famous elegy "To** (I keep in mind that magic moment...)" is firmly connected in consciousness of the majority of readers with the name of Anna Kern, the elegy "I loved you once..." doesn't have such a clear attribution and may, therefore, become a kind of emblem of a "hidden love" mythologeme, since it has mythologeme's general connotations of non-reciprocity, sadness, lasting, and fundamental incompleteness. The final wish "God bless you being loved by someone else" may indicate not humility, but on the contrary, the lasting feeling. Moreover, the pronoun "you" can be regarded as an appeal to all women, who in a greater or lesser extent caused a strong feeling in the poet.

\section{“UNREQUITED LOVE OF PUSHKIN" IN THE INTERPRETATION OF GUBER}

"I loved you once..." is dominated by the motive of "superior tranquility," that is the passion overcome, as shown by A. Zholkovsky in the article "Intertextual offspring." The scholar regards this elegy as a "cluster," a prism through which subsequent generations of poets develop the theme of unhappy love. The main content of the "I oved you once..." cluster is:

The theme of non-reciprocal love and other melancholic motifs; Pushkin wasn't indifferent to this genre, with its ambivalent interpretation of passion / dispassion; besides, there are also the themes of "unhappy or past love, love triangle, giving up the beloved to the another, renunciation." (2005:390)

P. Guber, who was able to unite "Don Juan list of Pushkin" with the "hidden love" mythologeme with the help of consistent interpretation (thereby resolving the dilemma that perplexed philosophers such as V. Soloviev and $M$. Gershenzon), wrote: "Pushkin owes unrequited passion the best times of his inspiration" (1993: 34).

A very characteristic reflection of this mythologeme is the book by $M$. Armalinsky Secret Notes of Pushkin. The text is written as a diary of Pushkin, reflects his relationships with numerous women but dedicated to his wife who was the only perfect beloved for the poet. Fans of this scandalous "diary" praise the author for returning the "canonized" image of Pushkin to "terrestrial" reality,

1 As L. Anninsky wrote, referring to Pushkin: "Our everything" - is our nothing?" Myth-making turned out to be at the sight of myth-fighting. 
for showing vivid image of the great poet, very far from austerities as well, for depth and artistic development of an erotic theme that is rare for Russian literature. Opponents of the text unequivocally call the text pornographic. Our point of view is that the book by Mikhail Armalinsky is paradoxically demythologizing and mythologizing Pushkin at the same time.

The demythologizing function of the text is associated with the author's focus onone side of the Pushkin myth - Pushkin's sexual relationships. The other sides of the image, such as a vulgar multiple repetition of "our everything," "Russian man in two hundred years," (or, according to an ironic clarification by A. Bitov, "not only our first poet, but also our first novelist, historian, citizen, professional, publisher, lyceum student, linguist, athlete, lover, friend" (1997:27) are taken off by M. Armalinsky (for with the exception of "lover"), as unnecessary clothes. Pushkin appears unusually and literally "naked."

By the laws of the novel genre, Secret Notes of Pushkin were passed on to the publisher by a person who was unable to be determined. Historical realities of the $19^{\text {th }}$ and the $20^{\text {th }}$ centuries: the legend of Pushkin's notes of his last months, which he allegedly bequeathed to publish not earlier than a hundred years after his death, the disappearance of the "historian" Nikolai Pavlovich, who found and decrypted the notes, emigration of "publisher" Armalinsky: in Pushkin-like fashion set out in "Necessary prefaces" (compare with The stories of the late Ivan Petrovich Belkin, published by A. P.). Even the style of notes is mentioned (notes translated from French by historian with no stylization tasks) differ from Pushkin's style. Nonetheless Pushkin's thoughts, known from Pushkin's letters, articles and other sources are skillfully added to the text, creating the illusion of the truth of this fictional narrative. In particular, the famous Pushkin's aphorism about Russian censorship and publication of erotic texts by I. Barkov as a demonstration of freedom of speech is noted by the "publisher" Armalinsky, meaning that the publication of the Secret Notes would be the next step towards liberation of the Russian press.

Not less important role in verifiability process of narration of the plot is played by Pushkin's peripheral biographical facts and participation of encrypted but easily recognizable historical figures of the Pushkin era. The newness of the interpretation is characterized by the images of N. N. Goncharova and d'Anthès. The first one of the images is the imitation of Pushkin poetry with such characteristics of the image of the beloved as "madona," "the purest sample of the purest beauty," despite the abundant use of taboo vocabulary, numerous descriptions of sexuality, initiated, however, by Pushkin himself in his correspondence with his wife. This oxymoronic combination is enhanced by the dedication of Secret Notes of Pushkin to his wife, colorfully illustrating the "Don Juan List of Pushkin" of the alleged author. The image of d'Anthès is devoid of demonic halo (compare with "the hand of the villain" in T. Tolstaya's work The plot, 1997: 97): he is shown as not devoid of wit "spoiled loafer," who fell under the "wheels" of Pushkin's fate. Armalinsky's Pushkin even falls under the spell 
of this man and almost consciously "chooses" d'Anthès who is "handsome as an angel" for the fateful duel. "Angelic" image of d'Anthès, as well as "madona" image of N. Goncharova is reduced by naturalistic descriptions of sex scenes, Sodom sin etc. Therefore, such an attitude to the killer of the poet is antithetical to the archetypical Lermontov's lines "with impudence he mocked and scorned the tongue and mores of this strange land..." ("Death of a Poet", 1837) (2013: 89). This Armalinsky's attitude to Pushkin and his duel is unique in Russianlanguage literature. looks unique.

\section{PUSHKIN - DON JUAN IN THE INTERPRETATION OF ARMALINSKY}

The fate of the poet is reinterpreted by M. Armalinsky extremely unusually. Many of Pushkin's poetic masterpieces are translated into laconic language of the Michel de Montaigne's Essays. Compare the lines from Pushkin's poem "To Yuriev" (1821):

But I, a roue forever idle,

Blacks' ugly descendant,

Grown up in wild simplicity,

In love, knowing no suffering,

I'm loved by young beauty

For my shameless rampage of desires... (1962: 112)

with an interpretation by M. Armalinsky:

Impatience is my very scourge. If desire inflames in me and it is drawn to some woman, then I want to take her that same minute. I cannot force myself to hold on to conditionals of decency, but thank God, most women like it. (2001: 136)

Compare Pushkin's poem “Memoirs" (1828):

And overtaken by disgust, my life I read, And quiver, and denounce in madness, And cry the bitter tears, and bitterly I plead,

But don't wash off the lines of sadness. (1962: 114)

with Armalinsky's text:

I am aware of my mistakes, but I do not correct them. This only confirms that we can see the fate, but are not able to change it. Understanding of mistakes is recognition of fate, and the impossibility of changing them is the power of fate. (2001: 164)

Secret Notes appeal to the "Tatiana's letter" from Pushkin's novel Eugene Onegin. Positivity and dynamism of the image of Tatiana, as it is known, are autobiographical for Pushkin. As well as the "Tatiana's letter," Notes are completed compositionally with a finale translated to a "modern" language: "I myself don't dare to reread what was written: fear of one's own abysses is too 
great." Compare with the ending of the letter from Pushkin's heroine: "Tis done! I scarce dare read it through."

\section{GENERAL IN THE INTERPRETATIONS OF GUBER AND ARMALINSKY: MENTAL DESOlATION OF PUSHIN AS A RESUlT OF ACHIEVING THE PERFECTION IN REALITY}

The argument about sense and meaning of translation (that the translation allowed to add modern intonation into Pushkin's language, bringing it closer to modernity) has particular importance. It is characteristic that the language is prosaic, like translation of Eugene Onegin by V. Nabokov. Nothing prevented the intended author from writing Secret Notes in verses if he were Pushkin. The only excuse is that in those mentioned years Pushkin was prone to "harsh" prose. Recall the well-known Tolstoy's assessment of The Belkin's Stories, that they were "naked somehow." Armalinsky's work with its "exposure of reception," with its concentration on the female sexual organ as the sense and the goal of Pushkin's poetry goes back, apparently, to Pushkin's famous letter to P. A. Vyazemsky about the marriage of Baratynsky (1826). Its essence is in the fact that marriage "empties the soul." Armalinsky consistently proves that Pushkin's wife consciously oriented her behavior on "Tatiana's dear ideal," thus was in some means that embodied ideal, and according to the thoughts of the author, appeared as an indirect cause of poet's untimely death. "Emptying of the soul" related to achievement of the ideal, both physical and moral, led, according to author's thoughts, to some kind of cessation in spiritual development of Pushkin.

Thus, Armalinsky's conclusion is in some means close to Guber's thoughts: unattainability of the ideal was giving impetus to creativity of the great poet, and "happiness on common ways" led to stagnation and creative crisis.

\section{BIBLIOGRAPHY}

ANNINSKY, L. (2002), “'Our everything' - is our nothing? Myth-creating at the sight of myth-fighting", Day of Literature, 1.

ARMALinKsY, M. (2001), Secret Notes of Pushkin 1836-183, Moscow, Ladomir, Russian Hidden Literature.

BITOV, A. G. (2007), Prayer for the Cup. The Last Pushkin, Moscow, Fortuna EL.

Bitov, A. G. (1990), The Pushkin House, Moscow, Izvestia.

BITOV, A. G. (1997), «GULAG as civilization», The Star, 27, 3-30.

Guber, P. (1999), The Don Juan list of Pushkin, Kharkiv, Delta.

EGorova, E. N. (2006), Shelter of Brooding Dryads, Moscow, Pushkin mansions and parks, Information center.

LERMONTOV, M. (2013), Collection of works in 10 volumes, vol. 1, Moscow, Voskresenie.

PUSHKIN, A. S. (1959-1962), Collection of works in 10 volumes, Moscow, GIHL.

TOlstAyA, T. (1997), Loves Me Not, Moscow, Olma-Press.

ZHOLKOVSKY, A. K. (2005), "Intertextual Offspring, 'I loved you once...' by Pushkin," Selected articles on Russian poetry: invariants, structures, strategies, intertexts, 390-431. 